\title{
DEALING WITH STRESS IN TEACHER PROFESSION: INDIVIDUAL AND ORGANIZATIONAL STRESS MANAGEMENT MEASURES
}

\author{
Egle Stasiunaitiene \\ Vytautas Magnus university, Lithuania \\ Ilona Kupcikiene \\ Kauno kolegija/ University of Applied Sciences, Lithuania \\ Lijana Navickiene \\ Kauno kolegija/ University of Applied Sciences, Lithuania
}

\begin{abstract}
Teaching is considered to be one of the most stressful professions. Bad social status of teacher in society, low salary, abundance of work roles, the need to work overtime, education reforms, disrespectful behavior of learners, high demands - all these factors and many others cause teachers" stress in their professional activity.

The study is aimed at identifying individual and organizational practices that are used to cope with teacher stress as well as finding out what are the main stress management gaps and areas which need to be improved at organization level and individually. A quantitative survey conducted in five European countries revealed that the most frequent stress management measures used at individual level relate to rational practices focused on managing thoughts and promoting rational and positive thinking. Also different organizational interventions are implemented at school level to promote teachers' motivation, participatory environment, open communication and support. However, these measures are insufficient. They need to be strengthened and expanded in order to promote more supportive work environment and trainings targeted to fill the gaps in school staff knowledge and skills on resolving conflicts and stress different management techniques.
\end{abstract}

Keywords: individual stress management measures, organizational stress management measures, school leaders' perspective, teachers' perspective, teachers' stress.

\section{Introduction}

Teaching is one of the professions in which a high level of emotional tension and stress is faced. High professional demands, unclear roles, increasing workloads, problematic relationships with students, parents and colleagues, noisy environment, abundance of paperwork are just few of the factors that lead to stressful situations in daily teachers' work. Therefore, anxiety, uneasiness and nervousness are common to many teaching professionals. This has a deleterious 
effect and negative impact on teachers' psychosocial, emotional and physical health, job motivation, causes teachers' burnout, poor job performance, high turnover rates and other unfavorable consequences (Prilleltensky, Neff, \& Bessell, 2016; Byers, 1987).

Stressful situations are unavoidable in teachers' work. The key things for maintaining proper emotional and physical health as well as job motivation are handling stress in a proper way, duly dealing with negative things, recognizing and managing them. For coping with stress certain interventions or measures may be applied.

The study aims to identify individual and organizational measures used to deal with teachers' stress. Also, the findings of the study allow revealing the main stress management gaps and areas which need to be improved at organization level and individually. For this a quantitative international research was performed.

\section{The Concept of Occupational Stress and Stress Management Measures in Pedagogical Practice}

Stress is linked to certain reactions when facing threatening or challenging situations. It is a consequence of all the pressures and demands occurring in the life (Karkockiene, 2011; Byers, 1987). Occupational stress may be understood as physiological, emotional, behavioral and cognitive responses to such factors as displeasing and pernicious work content, work organization, work environment, miscommunication. It is kind of imbalance between person's capabilities and the situation he or she finds himself or herself in. Because of this imbalance a person may feel frustration, tension or feeling of being overdemanded. Stress may result from heavy workload, high professional requirements, organizational expectations, conflict situations, psychological strain and other factors (Prilleltensky, Neff, \& Bessell, 2016). A number of surveys show clear links between stress and changes in person's physical, mental and emotional health, motivational and cognitive processes, psychological and social well-being (Karkockiene, 2011; Mahan et al., 2010; Chen, Wong, Ran, \& Gilson, 2009; McGregor, Antoni, Ceballos, \& Blomberg, 2008).

Stress management refers to efforts to neutralize stress and minimize its negative consequences. A great variety of measures may be applied for coping with stress. Some of them are to focus on stress sources- stressors, and aimed at changing them, i.e., eliminating a threat, fighting, or running away from a threat. These measures may include increasing knowledge and self-awareness of stress, developing time management and problem solving skills. Researchers usually call these stress management measures as preventive (Greenberg, Baron, 2003; Byers, 1987) or problem solving strategy (Almonaitiene, Lekaviciene, \& 
Antiniene, 2010; Cowley, 2006; Keith \&Wendy, 2014). When stressor is impossible to manage, i.e. a person is not able to have any impact on it, then measures to stabilize the emotional state and promote positive thinking are more appropriate. These measures are referred to as responsive strategy (Kompier, Cooper, \& Geurts, 2000). These two types of stress management strategies may be applied individually or at organizational level. It is widely argued that workplace stress management should be a shared responsibility of employers and managers. Individual stress management measures are related to individual changes, i.e., what a person can change in himself to overcome or avoid stress, whereas organizational stress coping measures include management efforts aimed at organizational change. The latter concept covers measures to remove stressors from the work environment and those designed to match the needs, knowledge and skills of the workers to the professional environment (Matteson \& Ivancevich, 1989; Byers, 1987). Organizational measures are interventions based on approach that focuses on changing the organization's culture to prevent stress from occurring and ensuring assumptions and opportunities for organizational support in coping with stress. These measures can be categorized in terms of changing tasks, roles, patterns of communication, cultural norms, psychological, support, mediation, etc. The survey of the scientific literature and pedagogical practices shows that educational institutions focus mostly on individual stress management measures.

\section{Methodology}

To reach the study aim a quantitative research was conducted. The survey was carried out in spring, 2018. Data for the study was gathered using two different online questionnaires (one for teachers, another for school leaders) that were sent to teachers and school leaders in Portugal, Slovenia, Bosnia and Herzegovina, Lithuania and Turkey. The questionnaires were developed by the authors of this paper. A random selection method of survey participants was used. In all 308 teachers and 62 school leaders from the aforementioned countries participated in the survey. The number of survey participants by country is provided in Table 1.The survey was anonymous, ensuring the confidentiality of the participants. Participants took part in the study voluntarily. These principles helped to ensure the reliability and objectivity of the collected data.

Table 1 Numbers of survey participants by country

\begin{tabular}{|l|c|c|c|c|c|}
\cline { 2 - 6 } \multicolumn{1}{c|}{} & Lithuania & Portugal & Slovenia & $\begin{array}{c}\text { Bosnia\& } \\
\text { Herzegovina }\end{array}$ & Turkey \\
\hline Teachers & 73 & 76 & 51 & 57 & 51 \\
\hline School leaders & 14 & 10 & 10 & 12 & 16 \\
\hline
\end{tabular}


The questionnaire for teachers is composed of two parts. The first part of the questionnaire includes questions related to teachers' stress level, individual and organizational stress management measures aiming at finding out the most common choices of individual practices used to deal with stress as well as organizational interventions or activities available for teachers to reduce their stress in professional activity. Stress management measures listed in in the questionnaire are grouped into four categories (Table 2).

\section{Table 2 Categories of stress management techniques (questionnaire for teachers)}

\begin{tabular}{|c|c|}
\hline $\begin{array}{c}\text { Category of stress management } \\
\text { methods }\end{array}$ & $\begin{array}{c}\text { Statement that describes stress management method in } \\
\text { the questionnaire }\end{array}$ \\
\hline \multirow{5}{*}{$\begin{array}{l}\text { Relaxation methods - soothing, } \\
\text { relaxing techniques that help to } \\
\text { regain well-being. These techniques } \\
\text { include physical activities, massages, } \\
\text { focus attention, body relaxation, } \\
\text { breathing, imagination and emotional } \\
\text { control exercises. }\end{array}$} & I practice relaxing with visual imagination techniques \\
\hline & I try to pay attention to breathing and do breathing exercises \\
\hline & $\begin{array}{l}\text { I try to calm down and relax in a creative way (for example, } \\
\text { drawing, writing, listening to music, etc.) }\end{array}$ \\
\hline & I exercise body relaxation exercises \\
\hline & I go to sport club after the classes \\
\hline \multirow{8}{*}{$\begin{array}{l}\text { Rational methods - include } \\
\text { deepening of self-perception and } \\
\text { cognition ways to strengthen the ego, } \\
\text { the establishment of clear and } \\
\text { flexible limits for self-determination, } \\
\text { learning to explore and manage } \\
\text { thoughts, promote rational and } \\
\text { positive thinking. }\end{array}$} & $\begin{array}{l}\text { I think over the stressful situation and develop an action plan } \\
\text { to cope with it }\end{array}$ \\
\hline & $\begin{array}{l}\text { I take some other work or activities to redirect my thoughts } \\
\text { from the issue }\end{array}$ \\
\hline & I make joke of the situation \\
\hline & I try to find something positive in the situation \\
\hline & I think over what I've learnt from the situation \\
\hline & I try to find out more about the situation \\
\hline & $\begin{array}{l}\text { I recall my previous successful experience of resolving the } \\
\text { problems }\end{array}$ \\
\hline & $\begin{array}{l}\text { I am convincing myself that I am a professional and have the } \\
\text { necessary skills to solve the problem }\end{array}$ \\
\hline \multirow{6}{*}{$\begin{array}{l}\text { Organizational methods - include } \\
\text { social support methods provided at } \\
\text { school for promoting proper } \\
\text { organizational microclimate, } \\
\text { relationships, open communication } \\
\text { and support. }\end{array}$} & I turn to my colleagues for help and/or advice \\
\hline & I share the problem with colleagues in the self-support group \\
\hline & $\begin{array}{l}\text { In communicating with my colleagues, I express the feelings } \\
\text { and seek consolation and understanding }\end{array}$ \\
\hline & I seek advice from a school psychologist \\
\hline & I ask for help from the school management \\
\hline & $\begin{array}{l}\text { In conflict with students, parents, colleagues, I address a } \\
\text { psychologist for mediation in conflict resolution }\end{array}$ \\
\hline Other & I take medicaments \\
\hline
\end{tabular}

The second part of the teachers' questionnaire (5 questions) was designed to find out teachers' views on what kind of help could be offered and promoted at organization level in order to support teachers in coping with stress more successfully in their professional life. The same questions also were put to school leaders. These questions allowed to determine and compare the attitudes of teachers and management staff towards the availability, need and impact of stress 
coping methods at organizational level (like supervision of school as an organization, trainings about conflicts, stress etc.) on teachers' stress level reduction.

\section{Research results}

Information about the survey participants. 62 school managers and 308 teachers participated in the study. The majority of school leaders (54\%) were of middle age (43-50), 37\% - between 26 and 42 years old, 29\% - 51-60 years old. $56 \%$ of school leaders who participated in the study were women. $40 \%$ of the management staff worked in primary schools, $40 \%$ - in secondary schools, $20 \%$ in vocational training institutions. The majority of teachers were women (86\%). $45 \%$ of teachers worked in primary schools, $47 \%$ - in secondary school and $8 \%$ in VET. The age distribution of the study participants-teachers was as follows: $61 \%$ were aged between 24-45, 26\% - between 46-55 and 13\% - between 56-65.

Teachers' stress level. Majority (61\%) of teachers reported their work as very stressful or stressful. View of school managers towards stress level in teacher work is even more worrying and decisive - almost $80 \%$ of school leaders consider teachers' job as very stressful or stressful (Figure 1).

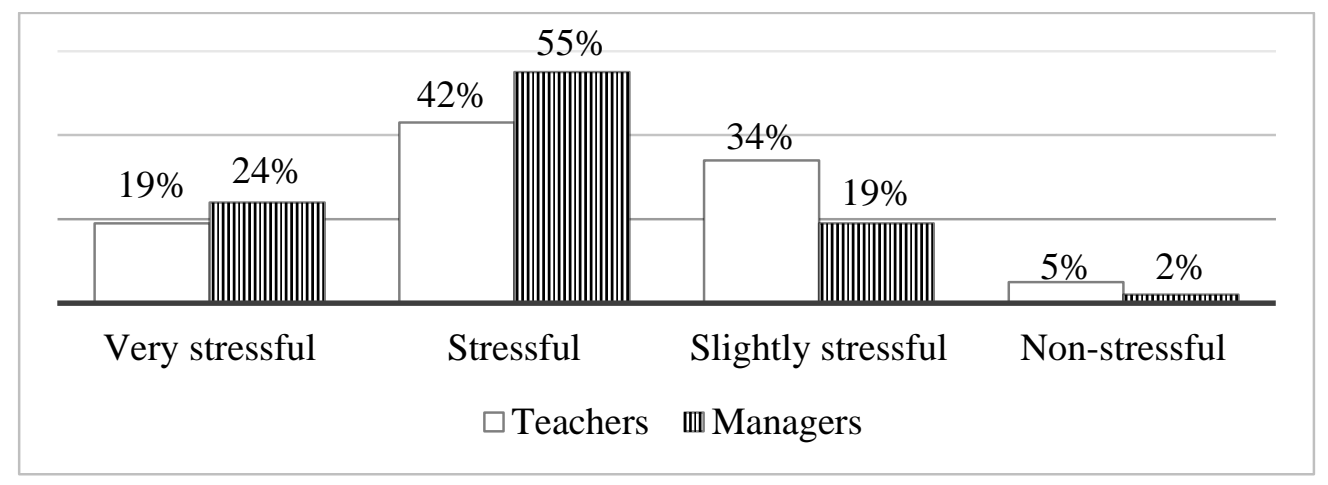

Figure 1 Teachers' work stress level - teachers and school managers' replies

According to research findings female teachers feel higher level of stress than man teachers. No significant difference in perceived stress level is found between teachers with different years of pedagogical experience. Number of students in class or education institution in which teachers work also do not have relevant impact on teachers' stress level.

Measures used by teachers to deal with stress. The results of the survey demonstrate that teachers are mostly focused on individual methods of coping with stress (Figure 2). Mostly, respondents employ cognitive or rational strategies for dealing with stress, such as reflecting on a stressful situation, recalling successful experiences in resolving a problem, reflecting on a problem-solving plan, redirecting thoughts from the problem situation to other activities, trying to 
find something positive in a situation, thinking about what has been learnt from the situation.

I am convincing myself that I am a professional and have the necessary skills to solve the problem

I think over what I've learnt from the situation

I calm myself down that I will overcome the difficulties

I recall my previous successful experience of resolving the problems

I think over the stressful situation and develop an action plan to cope with it

I try to find something positive in the situation

I take some other work or activities to redirect my thoughts from the issue

I try to find out more about the situation

In communicating with my colleagues, I express the feelings and seek consolation and understanding

I share the problem with colleagues in the self-support group

I try to calm down and relax in a creative way (for example, drawing, writing, listening to music, etc.)

I turn to my colleagues for help and/or advice

I make joke of the situation

I practice relaxing with visual imagination techniques

I try to pay attention to breathing and do breathing exercises

For a while, I set aside the problem, so that I could look at the situation later on

I exercise body relaxation exercises

I go to sport club after the classes

In conflict with students, parents, colleagues, I address a psychologist for mediation in conflict resolution

I ask for help from the school management

I seek advice from a school psychologist

I take medicaments

$\begin{array}{llllll}0 \% & 20 \% & 40 \% & 60 \% & 80 \% & 100 \%\end{array}$

$\square$ Constantly $\quad$ G Very often $\square$ Often $\boxminus$ Rarely $₫$ Never

\begin{tabular}{|c|c|c|c|}
\hline $23 \%$ & $33 \%$ & $31 \%$ & $3 \% \$ \%$ \\
\hline $22 \%$ & $8 \%$ & $28 \%$ & $13 \% 2 \%$ \\
\hline $22 \%$ & $33 \%$ & $30 \%$ & $13 \% 2 \%$ \\
\hline $21 \%$ & $34 \%$ & $29 \%$ & $12 \% 49$ \\
\hline $19 \%$ & 1408 & $25 \%$ & $19 \% 3 \%$ \\
\hline $18 \%$ & $33 \%$ & $28 \%$ & $17 \%-40$ \\
\hline
\end{tabular}

$17 \%$

$17 \%$

$14 \%]$

$14 \%]$

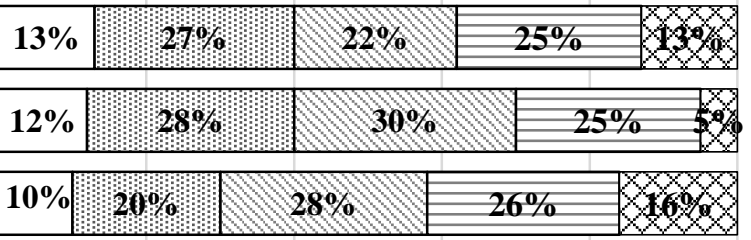
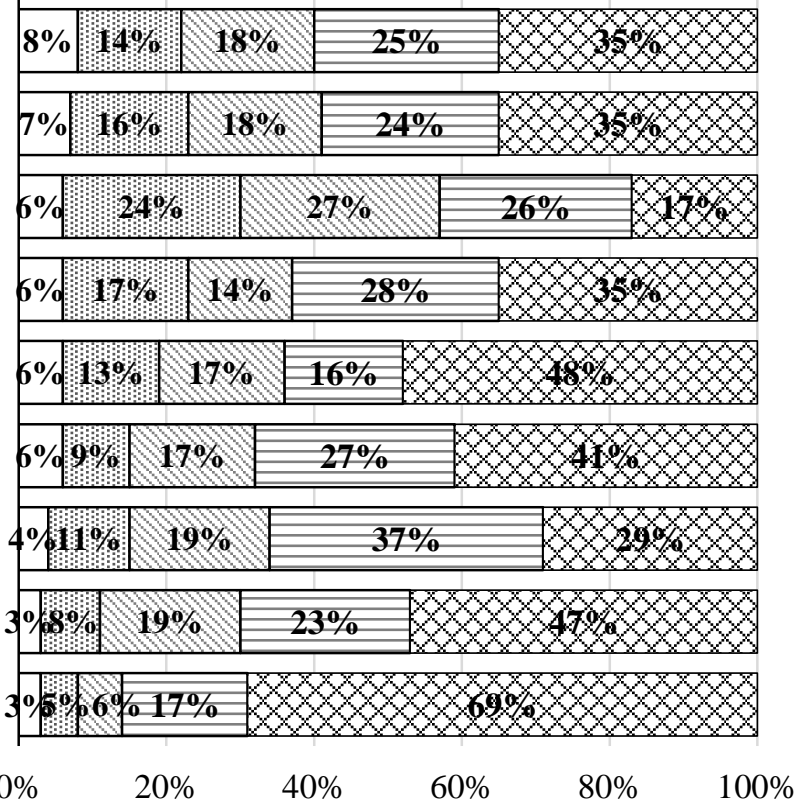

Figure 2 Measures used by teachers to manage stress 
Less than half of the respondents use various relaxation stress management measures, such as breathing and relaxation exercises, visual imagination techniques, physical activity. Survey data revealed that only a small proportion of respondents use medication to cope with professional stress.

Concerning organizational stress management measures teachers prefer to use some of the social support methods like sharing problematic situations with colleagues in self-support groups, communicating with colleagues, expressing the feelings and seeking consolation and understanding, or turning to the colleagues for help or advice. It is interesting to notice that less than half of the survey participants-teachers turn for help to the school management staff. And only a very small minority of respondents mentioned that they seek help and advices from a school psychologist. Analysis of measures used by teachers to cope with stress by countries does not show significant differences. The rational stress management techniques are the most preferred in all the countries. The least frequently reported activities are going to sport club and taking medicaments. Seeking advice from a school psychologists and asking for help from the school managers are more often used techniques by teachers in Turkey, also in Bosnia and Herzegovina than in Lithuania, Portugal and Slovenia.

Measures applied at schools for teachers' stress management. Analysis of school leaders' responses on measures that are implemented at schools to reduce teachers' stress level shows that diverse organizational interventions and activities are applied at school level to promote teachers' motivation, participatory environment, open communication and support. Most school managers state that events for staff to develop organizational culture based on cooperation and trust are organized, teachers are provided opportunities to take part in qualification development events, administrative staff responds to teachers' questions in a precise and immediate manner, motivates teachers for performance results, mediates in conflict situations, puts efforts to improve teachers' work environment. As the least frequently applied measures at school level are found to be invitations of supervisors to lead the team or organization supervisions and analysis on teachers' well-being at work.

Support and measures that teachers need in order to successfully overcome stress in their professional life are reflected in Figure 3. The results for support preferences comparing those of teachers and school leaders are very similar. Despite the fact that many school leaders report that a number of measures are applied at school to contribute to teachers' stress reduction, majority of school managers find that educational and skill-building methods aimed at improving personal abilities to deal with stress, like trainings on stress management techniques and resolving conflicts, would be a relevant help for teachers to cope with stress. These trainings are among the preferences among the teachers as well. The third area prioritized to be improved is the need of management staff support 
and efforts to promote better school climate. Supervision of the school as organization, according to teachers and school managers, is the least preferred measure to deal with stress. Almost half of the school managers find support of management and administration staff and regular professional activity reflection groups as relevant measures for promoting appropriate school's microclimate.

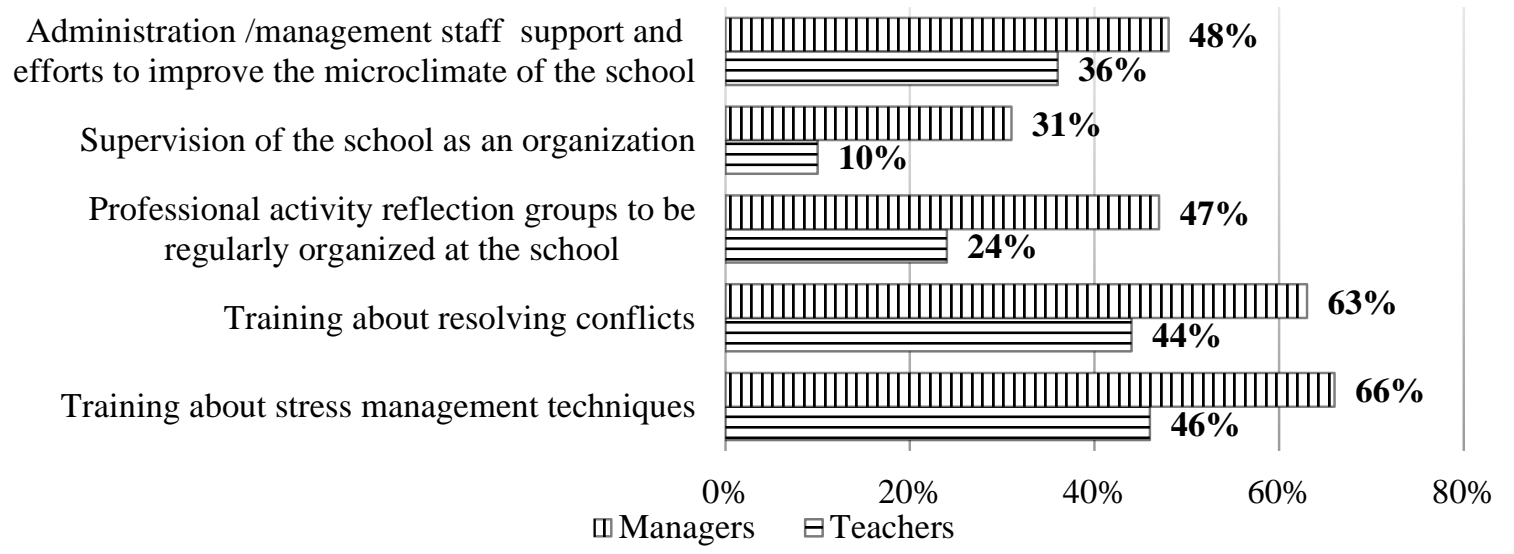

Figure 3 Measures for more successful teachers' stress management

Comparing the school leaders' preferences on the necessary stress management measures at school by countries (Figure 4), it is interesting to note that supervision of a school as an organization is the most preferred by Lithuanian school managers. Majority of the respondents from other countries do not think that this measure can play a significant role in reducing teacher professional stress.

Administration /management staff support and efforts to improve the microclimate of the school

Supervision of the school as an organization

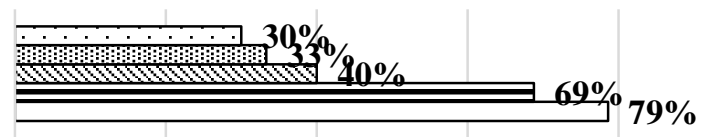
Supervision of the school as an organization

Training about resolving conflicts

Training about stress management techniques

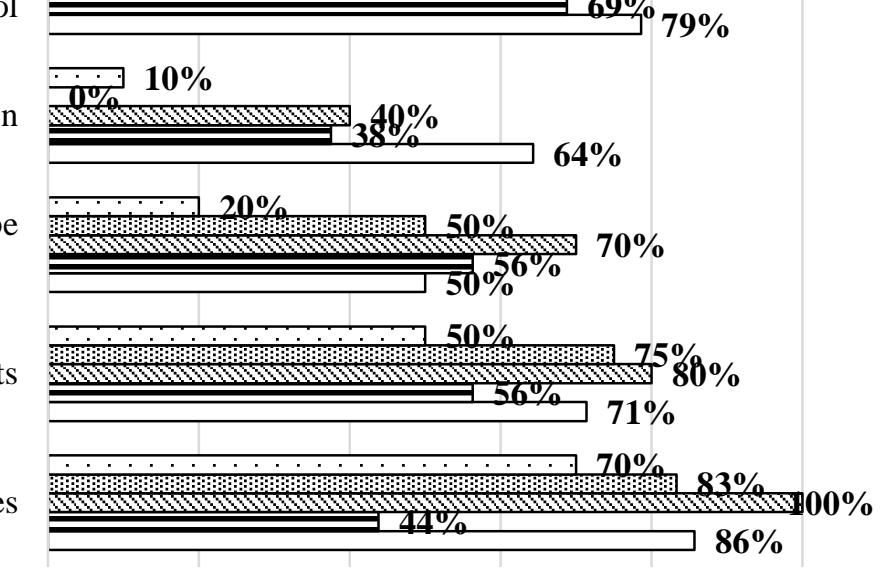

\begin{tabular}{|c|c|c|c|c|c|}
\hline & $0 \%$ & $20 \%$ & $40 \%$ & $60 \% \quad 80 \%$ & $100 \%$ \\
\hline 口Slovenia & 国Bosnia and Herzegovina & Q Portugal & 曰Turkey & $\square$ Lithuania & \\
\hline
\end{tabular}

Figure 4 Measures for more successful teachers' stress management - data by countries (school leaders' approach) 
School leaders from Portugal highlight the relevance of the regular organization of professional activity reflection groups as an effective stress management measure. Interestingly, training teachers stress management techniques for school managers from Turkey, unlike other countries, is the least preferred measure seeking teachers' stress decrease.

The research data allow to discover that majority of school leaders from Bosnia and Herzegovina, Portugal and Slovenia do not consider the role of the administration staff in improving the microclimate of the school as an important stress reducing measure for teachers.

\section{Conclusions}

1. Most measures for dealing with stress and applied by teachers are based on individual approach. Most commonly teachers use rational stress management methods focused on thoughts managements and positive thinking. Seeking advice from a school psychologists and asking for help from the school management are not much used measures by teachers, however teachers prefer to turn for help or advice to colleagues.

2. Basing on the survey of school leaders, a great variety of stress management measures are applied at schools to support teachers in dealing with professional stress. However, they need to be strengthened and expanded in order to promote more supportive work environment and enhance teachers' stress management skills.

3. School managers and teachers think that the most effective measures to deal with teachers' stress relate to educational and skill-building methods. Trainings about resolving conflicts and stress management techniques are treated as the most appropriate measures for teachers' stress management that should be promoted and applied at schools.

4. Not much importance is given to organizational stress management measures that are geared to organizational change. Management staff support and efforts to improve the microclimate of the school and organization of supervision of the school as an organization are considered as the least relevant measures for reducing teachers' occupational stress.

\section{Acknowledgements}

The research was conducted under the Erasmus plus project "Stress Free Teachers - Preventing Stress in the Teaching Profession” (2017-1-PT01-KA201035812). The authors of the paper thank partners from Slovenia, Portugal, Bosnia and Herzegovina and Turkey for their contribution and support in collecting the survey data. 


\section{References}

Almonaitiene, J., Lekaviciene, R., \& Antiniene, D. (2010). Žmonių santykiai organizacijoje. Kaunas: Technologija.

Byers, S.K. (1987). Organizational stress: Implications for health promotion managers. American Journal of Health Promotion, 2(1), 21-27. DOI: https://doi.org/10.4278/08901171-2.1.21

Chen, H., Wong, Y., Ran, M.S., \& Gilson, Ch. (2009). Stress among Shanghai University Students. The Need for Social Work Support. Journal of Social Work, 9, 323-344. Retrieved from http://jsw.sagepub.com/content/9/3/323.full.pdf+html

Cowley, S. (2006). Mokymo klinika. Vilnius: Tyto alba.

Greenberg, J., \& Baron, R.A. (2003). Behavior in Organization: Understanding and Managing the Human Side of Work. Upper Sadle River: Prentice Hall.

Karkockiene, D. (2011). Medicinos ir sveikatos mokslų studentų patiriamo streso ypatumai ir jo įtaka miego kokybei. Visuomenés sveikata, 2(53), 83-92.

Keith, C.H., \& Wendy, M.R. (2014). Stress Management for Teachers: A Proactive Guide. New York: The Guilford Press.

Kompier, A.J., Cooper, C.L., \& Geurts, A.E. (2000). A multiple case study approach to work stress prevention in Europe. Europe Journal of Work and Organizational Psychology, 9(3), 85-112.

Mahan, P.L., Mahan, M.P., Park, N.J., Shelton, C., Brown, K.C., \& Weaver, M.T. (2010). Work Environment Stressors, Social Support, Anxiety, and Depression among Secondary School Teachers. Workplace health and safety, 58(5), 197-205. Retrieved from https://journals.sagepub.com/doi/abs/10.1177/2165079910058005044

Matteson, M.T., \& Ivancevich, J.M. (1989). Controlling Work Stress: Effective Human Resource and Management Strategies. San Francisco: Jossey-Bass Publishers.

McGregor, B.A., Antoni, M.H., Ceballos, R., \& Blomberg, B.B. (2008). Very low CD19+ Blymphocyte percentage is associated with high levels of academic stress among healthy graduate students. Stress and Health, 24. 413-418. Retrieved from http://web.ebscohost.com/ehost/pdf?vid=22\&hid=105\&sid=52c0e842-56dc-40e2-a0a337c4d7cdac43\%40sessionmgr114

Prilleltensky, I., Neff, M., \& Bessell, A. (2016). Teacher Stress: What It IS, Why It's Important, How It Can be Alleviated. Theory into Practice, 55, 104-111. Retrieved from https://www.tandfonline.com/doi/abs 